Slađana Sredojević

Udruženje banaka Srbije sladjana.sredojevic@ubs-asb.com

Prevod obezbedio

autor
PERSPEKTIVE

INVESTIRANJA

U OBLASTI

OBNOVLJIVIH IZVORA ENERGIJE U REPUBLICI SRBIJI

\title{
Rezime
}

Obnovljivi izvori energije je, pored energetske efikasnosti, oblast koja je veoma perspektivna, čiji je značaj rastući i na globalnom tržištu. Ona je bazirana na složenom i obimnom setu regulative i nadzora, kako u domaćim tako i međunarodnim okvirima. Da bi se planovi postavljeni u ovim oblastima uspešno realizovali i registrovali kao veća upotreba obnovljivih izvora energije, neophodna je saradnja sa bankarskim sektorom koji će prvenstveno finansijskom podrškom i ekspertizom biti ključni partner u implementaciji mnogih projekata javnog i komercijalnog karaktera. Rad se bavi analizom mogućnosti koje regulatorni okvir u Republici Srbiji otvara u oblasti obnovljivih izvora energije, kroz zakonski okvir i mehanizme koji uređuju prirodu odnosa između raznih zainteresovanih strana. Osnovna pretpostavka u istraživanju je da dobra regulativa na direktan način omogućava predvidivost prihoda u projektu, što direktno utiče na smanjenje troškova i rizika finansiranja. Takođe, rad analizira i izazove koje bi trebalo prevazići u budućnosti i daje preporuke mogućih daljih aktivnosti usmerenih u cilju obimnijeg finansiranja, kao i opšteg unapređenja nivoa svesti o značaju projekata obnovljivih izvora energije i uloge banaka u njihovom finansiranju.

Ključne reči: obnovljivi izvori energije, banke, finansiranje, javno-privatno partnerstvo, investiranje, investitori, projektno finansiranje. 


\section{INVESTMENT OPPORTUNITIES IN THE FIELD OF RENEWABLE ENERGY SOURCES IN THE REPUBLIC OF SERBIA}

Slađana Sredojević

Association of Serbian Banks sladjana.sredojevic@ubs-asb.com
Translation provided by the author

\section{Summary}

Energy efficiency and renewable energy are areas that are very promising, with the growing importance on the global marketplace. These are based on large and complex sets of regulations and controls, at both domestic and international level. In order to successfully fulfil the targets set in these areas including the greater registered use of renewable energy sources, it is required to boost cooperation with the banking sector, which may, primarily owing to its financial support and know-how, be the key partner in the implementation of many public and commercial projects. The paper analyzes the opportunities that the regulatory framework in the Republic of Serbia introduced in the field of renewable energy, including the legal framework and mechanisms that regulate the nature of the relationship between various stakeholders. The basic premise of the research is that the good regulations aim to provide predictability of income in the project, which has a direct impact on the reduction of costs and risks related to financing. Also, the paper analyzes the challenges that should be overcome in the future and recommends the possible further activities towards the more comprehensive funding, improvement of the general level of awareness about the importance of renewable energy projects and the role of banks in financing their further development.

Keywords: renewable energy sources, banks, financing, public-private partnership, investments, investors, project financing 


\section{Uvod}

U 2006. godini u Republici Srbiji je usvojen Zakon o ratifikaciji ugovora o osnivanju Energetske zajednice između Evropske zajednice i Republike Albanije, Republike Bugarske, Bosne i Hercegovine, Republike Hrvatske, BJR Makedonije, Republike Crne Gore, Rumunije, Republike Srbije i privremene misije UN na Kosovu u skladu sa rezolucijom 1244 Saveta bezbednosti UN. U skladu sa Ugovorom o osnivanju Energetske zajednice, ugovorne strane su se obavezale i da usklade svoje sa propisima EU o obnovljivim izvorima energije, zaštiti životne sredine i energetskoj efikasnosti. Trenutno, u svim zemljama Energetske zajednice $\mathrm{u}$ toku su pripreme za primenu Direktive o velikim ložištima od 1. januara 2018. godine. Studija Energetske zajednice iz 2013. godine pokazala je da bi na Zapadnom Balkanu koristi od primene direktiva o velikim ložištima i industrijskim emisijama premašivali troškove u razmeri od čak 15 puta. Ipak, kada je reč o regionalnim kretanjima, postoji visoki i prihvaćeni konsenzus da svakako treba razvijati obnovljive izvore energije i u toj oblasti sve zemlje regiona, osim Hrvatske, i dalje jesu u početnoj fazi.

Prema procenama Ministarstva rudarstva i energetike Republike Srbije, Srbija proizvodi 70 odsto električne energije iz termoelektrana, ukupne (skromne) proizvodnje struje 38 teravat časova (TWh) uz visok nivo tzv. spoljnih troškova (nepovoljan uticaj na životnu sredinu i zdravlje). Republika Srbija je usvojila zakonski okvir koji stimuliše proizvodnju električne energije i drugih energenata iz obnovljivih izvora energije, razvijaju se projekti iz oblasti obnovljivih izvora energije, Srbija ima tzv. feed-in tarife, odnosno podsticajne cene za proizvodnju struje iz tih izvora energije, i postoje visoka očekivanja za velika ulaganja u hidroelektrane: veliki potencijal od 17 do 18 TWh iz velikih hidroelektrana koji se može tehnički upotrebiti, od čega je iskorišćeno 11 TWh na najboljim lokacijama. Takođe, očekuje se izgradnja velikih vetroparkova od 489 megavata, za koje je već odobren status privremeno povlašćenog proizvodjača, odnosno počeli su da teku rokovi za izgradnju tih velikih objekata. Po procenama Ministarstva, ukupno, u Srbiji se planiraju projekti koji će omogućiti 1.090 megavata iz obnovljivih izvora energije.

Sve ovo ukazuje na perspektivnost finansiranja projekata obnovljivih izvora energije u Republici Srbiji. U daljem tekstu biće dat detaljniji prikaz mogućnosti ovog tržišta i specifičnosti gledišta i potencijala činilaca ili aktera na njemu.

\section{Značaj i svrha projekata obnovljivih izvora energije u svetu $i$ kod nas}

Obnovljivi izvori energije (OIE) su prirodni resursi kao što su energija vode, vetra, sunca, geotermalna energija i bio energija (bio gas, bio gorivo, bio masa). Najčešći projekti koji se realizuju u ovoj oblasti, koristeći navedene resurse kao izvore, jesu finansiranje i izgradnja hidroelektrana, elektrana na biomasu, elektrana na biogas, elektrana na gas iz komunalnih otpadnih voda, elektrana na vetar, solarnih elektrana, geotermalnih elektrana, elektrana na otpad. Solarne termalne energane su izvori električne struje dobijene pretvaranjem sunčeve energije $\mathrm{u}$ toplotnu, $\mathrm{u}$ poređenju sa procesom fotovoltaika kod kojih se električna

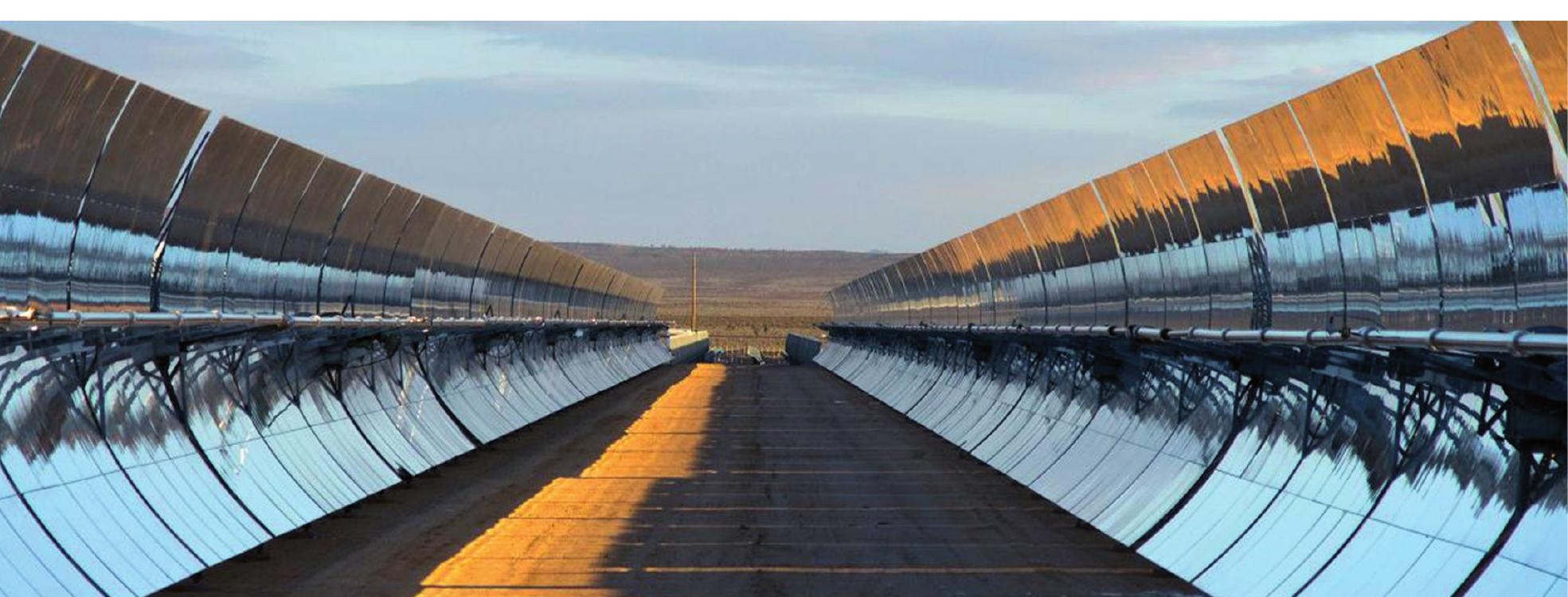




\section{Introduction}

In 2006 the Republic of Serbia adopted the Law on ratification of the treaty establishing the Energy Community between the European Community and the Republic of Albania, Bulgaria, Bosnia and Herzegovina, Croatian Republic, FYR Macedonia, Montenegro, Romania, Serbia, and the UN Interim Administration Mission in Kosovo in accordance with resolution 1244 of the Security Council. In accordance with the Treaty establishing the Energy Community, the parties have committed to harmonize their regulations with the EU regulations on renewable energy sources, environmental protection and energy efficiency. Currently, all countries of the Energy Community are in the middle of preparations for the implementation of the Directive on Large Combustion Plants starting from 1 January 2018. The Study of the Energy Community in 2013 showed that the potential benefits from the application of the Directive on Large Combustion Plants and Industrial Emissions in the Western Balkans would exceed the costs of its implementation by up to 15 times. However, when it comes to regional developments, there is a high consensus for further development of renewable energy sources with all the countries of the region, except Croatia, still being in the initial stage.

According to the Ministry of Mining and Energy of the Republic of Serbia, Serbia produces 70 percent of electricity from thermal power plants, with a total (modest) electricity production of 38 terawatt hours (TWh), recording the high levels of the socalled external costs (an adverse impact on the environment and health). The Republic of Serbia has adopted a legal framework that stimulates the production of electric and other energy from renewable energy sources, and has been developing projects in the field of renewable energy sources. Moreover, Serbia has feed-in tariffs, as incentive prices for the production of electricity from these sources of energy, and there are high expectations for large investments in hydroelectric power: the great potential of 17 to 18 TWh from large hydropower plants that can be technically used, 11 TWh of which has been utilized in the best locations. Also, the construction of large wind farms of $489 \mathrm{MW}$ is expected, and they have already been granted the status of a temporary privileged producer, with active deadlines for the construction of these large objects. According to the Ministry, Serbia has planned projects that will enable the total of 1,090 megawatts of renewable energy.

All these examples show the good prospects of financing renewable energy projects in the Republic of Serbia. Hereinafter, a more detailed view of the market will be analyzed as well as the specific perspectives and potential of the market participants.

\section{Importance and purpose of Renewable Energy Sources projects at the global and national scale}

Renewable energy sources (RES) are natural resources such as hydropower, wind, solar, geothermal and bio energy (biogas, biofuels, and biomass). The most common projects that are being implemented in this field, using these resources as sources, are the financing and construction of hydropower plants, biomass power plants, biogas plants, gas power plants using urban waste water, wind power, solar power, geothermal power plants, and waste power plants. Solar thermal power plants are sources of electricity obtained by converting solar energy into heat, as opposed to the photovoltaic process which provides electricity directly. Since they have no harmful products during the production of electricity, and their efficiency is high (20 to $40 \%$ ) they are considered as very promising projects for the construction and financing in the future. On the other hand, the share of biomass in energy production in Serbia is indeed negligible, although the country (eastern Serbia) has a huge potential for the production of electric and heat energy from biomass. Biomass is one of the largest renewable energy sources, and Serbia is among the top European countries in terms of the amount of unused biomass. According to the earlier estimates, the total biomass energy potential in Serbia amounts to 3.1 million tons of oil equivalent: wooden biomass 1.5 million and agricultural biomass 1.6 million (Renewable Energy, 2016). The benefits of such a large amount of resources and energy are universal 
energija dobija direktno. Pošto nemaju štetnih produkata prilikom proizvodnje električne energije, a efikasnost im je velika (20 do $40 \%$ ), vrlo su perspektivni projekti za izgradnju i finansiranje $\mathrm{u}$ budućnosti. Sa druge strane, učešće biomase $u$ proizvodnji energije $u$ Srbiji je zaista zanemarljivo, ali u zemlji (istočna Srbija) postoje ogromni potencijali za proizvodnju eletrične i topotne energije iz biomase. Biomasa je jedan od najvećih obnovljivih izvora energije, a Srbija spada $u$ vrh evropskih zemalja po količini neiskorišćene biomase. Prema ranijim procenama, ukupan energetski potencijal biomase u Srbiji iznosi 3,1 miliona tona ekvivalentne nafte: drvna biomasa: 1,5 miliona i poljoprivredna: 1,6 miliona (Obnovljivi izvori energije, 2016).

Koristi od tako velikog potencijala i količine energije su univerzalne i postoje $u$ svim delovima sveta. Tako, i kada je reč o Republici Srbiji, koristi bi imali ne samo potrošači, nego i finansijeri, banke, kompanije privatnog sektora i društvo u celini.

\section{Analiza osnova regulatornog okvira kao pretpostavke finansiranja $u$ oblasti OIE u Srbiji}

Mogućnosti finansiranja projekata OIE su, između ostalog, definisani i domaćom regulativom iz te oblasti. Specifičnost oblasti OIE, kao i kod oblasti energetske efikasnosti, nalazi se $\mathrm{u}$ tome što je legislativa kompleksan set domaćih i međunarodnih propisa i pravila koji definišu odnose između različitih strana. $U$ daljem tekstu, biće dat prikaz glavnih aspekata relativno složene regulative u ovoj oblasti.

- Međunarodna regulativa je snažan pokretač poslovnih mogućnosti u ovoj oblasti. Obaveza transponovanja Direktive 2009/28/EC ("Directive on the promotion of the use energy from renewable energy sources", Evropska komisija, 2009) se odnosi na promociju korišćenja obnovljivih izvora energije i njome je definisan cilj prema kojem bi u Evropskoj Uniji do 2020. godine udeo obnovljivih izvora energije (OIE) u potrošnji finalne energije bio najmanje $20 \%$, pri čemu bi biogorivo učestvovalo sa najmanje $10 \%$ $\mathrm{u}$ potrošnji goriva u saobraćaju. Takođe, odluka Ministarskog saveta Energetske zajednice iz 2012. godine (Decision 2012/04/ MC - EnC on the implementation of Directive 2009/28/EC and amending Article 20 of the Energy Community Treaty) predviđa dostizanje obavezujućeg udela obnovljivih izvora energije od $27 \% \mathrm{u}$ bruto finalnoj potrošnji energije. Inače, obaveza je države da glavnu legislativu u oblasti energetike $u$ velikoj meri uskladi sa Trećim energetskim paketom EU, u skladu sa Ugovorom o osnivanju energetske zajednice, naročito $\mathrm{u}$ oblastima električne energije, gasa i obnovljivih izvora energije.

- Domaći zakoni korespondiraju međunarodnim trendovima i preuzetim obavezama. Domaća regulativa u oblasti obnovljivih izvora energije treba da omogući investicije u ovim oblastima; osnove su postavljene Zakonom o energetici (Ministarstvo rudarstva i energetike, 2014) i brojnim podzakonskim aktima. Zakon o energetici, usvojen u decemrbu 2014, uvodi novu licencu za snabdevanje električnom energijom na veliko $\mathrm{u}$ vezi sa trgovanjem električnom energijom na tržištu prodaje električne energije na veliko, sa izuzetkom prodaje električne energije krajnjim kupcima.Zakon uvodi i pojam garantovanog snabdevanja, definiše proceduru za odabir garantovanog snabdevača putem tendera, kao i odabir rezervnog snabdevača. Domaćinstva i mali kupci imaju pravo da biraju snabdevače električnom energijom i gasom, a takođe će imati i mogućnost garantovanog snabdevanja. Inače, u proteklom periodu (jun 2016) usvojen je i niz podzakonskih akata kojima se omogućava dalja primena Zakona o energetici.

- Nacionalni akcioni plan za korišćenje obnovljivih izvora energije (u daljem tekstu: NAPOIE) je dokument kojim se utvrđuju ciljevi korišćenja obnovljivih izvora energije do 2020. godine, kao i načini za njihovo dostizanje. Između ostalog, on ima za cilj i da podstakne investiranje $u$ oblasti obnovljivih izvora energije. Izrada NAPOIE u formi pitanja i odgovora, proistekla je iz prethodno navedene međunarodne obaveze koju je Republika Srbija preuzela 2006. godine Zakonom o ratifikaciji ugovora o osnivanju Energetske 
and exist in all parts of the world. So, when it comes to the Republic of Serbia, the benefits would be recorded not only for the consumers, but also for financiers, banks, private sector companies and society as a whole.

\section{Analysis of the regulatory framework as a premise for Renewable Energy Sources Financing in Serbia}

The opportunities for financing of RES projects are defined, among other things, by the domestic regulation in this area. The specificity of the field of renewable energy, as well as of energy efficiency, is the fact that the legislation is in the form of a complex set of national and international regulations and rules that define the relationships between different parties. Hereinafter, we will show the main aspects of the relatively complex regulation in this area.

-International regulation is a powerful driver of business opportunities in this field. The obligation to transpose Directive 2009/28 / EC ("Directive on the promotion of the use of energy from renewable energy sources", European Commission, 2009) refers to the promotion of the use or renewable energy sources and the thereby defined objective according to which by 2020 the European Union will achieve the share of renewable energy sources in the final energy consumption no less than $20 \%$, where biofuel accounts for at least $10 \%$ in the fuel consumption in transport. Also, the decision of the Ministerial Council of the Energy Community in 2012 (Decision 2012/04 / MC - EnC on the implementation of Directive 2009/28 / EC and amending Article 20 of the Energy Community Treaty) predicts the reaching of a binding share of renewable energy sources of $27 \%$ in the gross final consumption of energy. Otherwise, it is the state that is obliged to harmonize the main legislation in the field of energy largely with the Third Energy Package of the EU, in accordance with the Treaty establishing the Energy Community, in particular in the fields of electricity, gas and renewable energy sources.

- National laws corresponding to international trends and commitments. Domestic regulation in the field of renewable energy sources should enable investments in these areas; the foundations were set by the Energy Law (Ministry of Mining and Energy, 2014) and a number of by-laws. The Energy Law, adopted in December 2014, introduces a new license for the wholesale supply of electricity in relation to the energy trading on the wholesale electricity market, with the exception of the sale of electricity to end customers. The law introduces the concept of guaranteed supply, defines the procedure for the selection of guaranteed suppliers through tenders and the selection of a backup supplier. Households and small customers have the right to choose their suppliers of electricity and gas, and will also have the possibility of guaranteed supply. Otherwise, in the previous period (June 2016) a set of by-laws was adopted, allowing further implementation of the Energy Law.

- The National Action Plan for renewable energy sources (hereinafter: NREAP) is a document which defines the objectives of the use of renewable energy sources by 2020, and how to achieve them. Among other things, it also aims to encourage investments in renewable energy. The creation of NREAP in the form of questions and answers, resulted from the aforementioned international obligations that the Republic of Serbia assumed pursuant to the 2006 Law on the ratification of the treaty establishing the Energy Community between the European Community and the Republic of Albania, Bulgaria, Bosnia and Herzegovina, Republic of Croatia, the former Yugoslav Republic of Macedonia, Montenegro, Romania, Serbia and the United Nations Interim Administration Mission in Kosovo in accordance with resolution 1244 of the United Nations ("Official Gazette of RS", No. 62/06). Under this Agreement, the

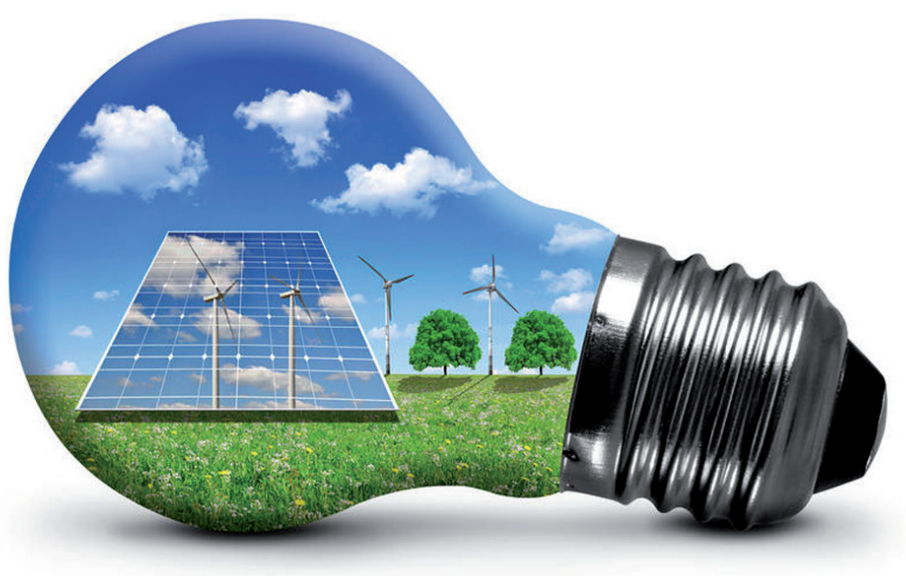


zajednice između Evropske zajednice i Republike Albanije, Republike Bugarske, Bosne i Hercegovine, Republike Hrvatske, Bivše jugoslovenske Republike Makedonije, Republike Crne Gore, Rumunije, Republike Srbije i Privremene misije Ujedinjenih Nacija na Kosovu u skladu sa rezolucijom 1244 Saveta bezbednosti Ujedinjenih nacija ("Službeni glasnik RS", broj 62/06). Prema ovom Ugovoru, obaveza Srbije je da poveća učešće OIE $\mathrm{u}$ bruto potrošnji finalne energije sa $21,2 \%$ koliko je iznosilo u 2009. godini na $27 \%$ do 2020. godine.

- Uvođenje niza novih sistema učinjeno je po ugledu na najbolju praksu u ovoj oblasti, kao što je, između ostalog sistem korišćenja podsticajnih mera kojima država pomaže uspostavljanje i funkcionisanje sistema finansiranja privatnog sektora. Uredba o naknadi za podsticaj povlašćenih proizvođača električne energije doneta je na osnovu odredbe 79. stava 3. Zakona o energetici ("Službeni glasnik RS", broj 145/14) kojom je određeno da Vlada propisuje način obračuna, plaćanja i prikupljanja sredstava po osnovu naknade za podsticajne mere, kao i način raspodele prikupljenih sredstava po osnovu naknade za podsticajne mere.

Imajući to u vidu, zaključuje se da je potencijal za finansiranje ovih projekata ogroman i banke imaju mogućnost da se blagovremeno pozicioniraju u skladu sa ovim predstojećim i rastućim potrebama različitih javnih tela (javnog sektora). Rad se dalje detaljnije bavi analizom na nivou instituta i mehanizama koji su $u$ regulativi uspostavljeni, a koji vrlo pogoduju kako opštoj predvidivosti i stabilnosti poslovnog dugoročnog aranžmana, kakvi su projekti u oblasti OIE, tako i položaju i interesu banaka, potencijalnih investitora i finansijera.

\section{Mehanizmi domaće regulative od značaja za investitore $\mathbf{i}$ banke $u$ projektima OIE}

U oblasti obnovljivih izvora energije, novi Zakon o energetici je uveo niz poboljšanja, uključujući i jasniji program podsticajnih mera. Od mnogih poboljšanja, sa aspekta postojećih i potencijalnih stranih investitora, najvažniji segmenti su produženje trajanja statusa privremenog povlašćenog proizvođača električne energije $\mathrm{u}$ slučaju projekata proizvodnje električne energije, dozvola privremenom povlašćenom proizvođaču električne energije da zaključi ugovor o otkupu električne energije sa kupcem, kao i mogućnost investitora, odnosno budućeg proizvođača energije, da sam izgradi priključak na mrežu u ime operatera (Savet stranih investitora, 2015, 23).

Značajna su poboljšanja i sa drugih stanovišta, koja novi Zakon o energetici uvodi $\mathrm{u}$ oblasti obnovljivih izvora energije, kao npr. jasnija pravila u pogledu prioritetne isporuke $\mathrm{i}$ odnosne obaveze sistema za transport prirodnog gasa i distributivnog sistema prirodnog gasa da obezbede prioritetni pristup proizvođačima električne energije iz obnovljivih izvora priključku i otkup ukupne proizvedene energije, osim ako to ne ugrožava funkcionisanje sistema. Među značajnija poboljšanja zakonskog okvira ističe se i diskreciono pravo dato investitoru, odnosno budućem proizvođaču energije, da sam izgradi priključak na mrežu u ime operatera, kao i da kontroliše proces izgradnje priključka. Ova novina je od ogromne važnosti ne samo za investitore, nego i za potencijalne finansijere, kao i za velike projekte.

Pored samog Zakona o energetici, poboljšanja su omogućena aktuelnostima, preciznošću i mehanizmima koje su predvideli i podzakonski akti, kao što su:

1. Uredba o uslovima i postupku sticanja statusa povlašćenog proizvođača električne energije, privremenog povlašćenog proizvođača i proizvođača električne energije iz obnovljivih izvora energije ("Službeni glasnik RS", broj 56/2016) koja detaljnije definiše razlike između kategorija povlašćenih proizvođača, koji se sada dele na: privremene povlašćene proizvođače električne energije, povlašćene proizvođače električne energije i proizvođače električne energije iz obnovljivih izvora. Takođe, njome se određuje način sticanja statusa povlašćenog proizvođača električne energije (za izgrađen objekat i priključen objekat), statusa privremenog povlašćenog proizvođača električne energije (minimalno građevinska dozvola, finansijski instrument obezbeđenja), status proizvođača električne energije iz OIE (izgrađen objekat, priključen objekat). 
obligations of Serbia are to increase the share of RES in the gross final energy consumption from $21.2 \%$ recorded in 2009 to $27 \%$ by 2020.

- The introduction of a series of new systems has been done according to the model of best practice in this field, such as, inter alia, the use of the system of incentives by which the state helps the establishment and functioning of the system of financing the private sector. The regulation on the compensation for stimulating the privileged power producers was made on the basis of the provisions of paragraph 3 of Article 79 of the Law on Energy ("Official Gazette of RS, No. 145/14) stating that the Government shall prescribe the method of calculation, payment and collection of funds based on the charges for incentives, as well as the method of allocating the funds collected from the fees for incentives.

Bearing in mind the above, it is concluded that the potential for funding of these projects is huge and the banks have the ability to timely position themselves in accordance with these upcoming and growing needs of the various public bodies (public sector). The research further analyzes the institutes and mechanisms brought in place by the regulations, which are very favorable for both the general predictability and stability of long-term business arrangements, such as projects in the field of RES, as well as the position and interests of banks, potential investors and financiers.

\section{Mechanisms of domestic legislation relevant for investors and banks in RES projects}

In the area of renewable energy sources, the new Energy Law has introduced a number of improvements, including a clear program of incentives. Among many improvements important for the existing and potential foreign investors, the most important aspects are the prolongation of the temporary status of a privileged producer of electricity in the case of electricity production projects, permission for temporary privileged producer of electricity to conclude a purchase of electricity contract with the customers, and the ability of investors and future energy producers to construct a connection to the network on behalf of the operator (FIC, 2015, 23).

Moreover, from the other points of view, there are significant improvements that the new Energy Law introduces in the field of renewable energy, such as the clearer rules regarding the priority of delivery and the respective obligations of the transportation of natural gas and natural gas distribution system to provide priority access to the connection for the producers of electricity from renewable sources, as well as the purchase of the total energy produced, unless it endangers the functioning of the system. Also, as one of the major improvements of the legal framework is the discretionary right given to the investor or a future energy producer to build a connection to the network on behalf of the operator, as well as to control the process of the construction of the connection. This novelty is of great importance not only for investors but also for potential financiers, as well as for large projects. In addition to the Energy Law, the actual improvements, precisions and mechanisms are enabled and anticipated also by the relevant bylaws, such as:

1. Regulation on conditions and procedure for acquiring the status of a privileged electricity producer, temporary privileged producer and the producers of electricity from renewable energy sources ("Official Gazette of RS", No. 56/2016), which defines in detail the differences between the categories of privileged producers, which are now divided into: temporary privileged electricity producers, privileged electricity producers and producers of electricity from renewable sources. Also, it determines the manner of acquiring the status of privileged power producers (the object was built and connected), the temporary status of a privileged producer of electricity (minimum building permit, financial security instrument), the status of producers of electricity from renewable energy sources (built and connected object).

The duration of the temporary status of a privileged producer of electricity in the case of projects of electricity production from wind power is now three years (instead of two in the previous Act) with the possibility of extension for another year. The same applies to the hydroelectric power plant with installed 
Trajanje statusa privremenog povlašćenog proizvođača električne energije u slučaju projekata proizvodnje električne energije iz snage vetra sada iznosi tri godine (umesto dve iz prethodnog zakona) sa mogućnošću produženja na još godinu dana. Isto se odnosi i na hidroelektrane čija instalisana snaga iznosi do $30 \mathrm{MW}$, kao i za elektrane na biomasu, biogas, otpad i geotermalne elektrane. Trajanje statusa povlašćenog proizvođača je na neodređeno vreme. Status povlašćenog proizvođača i privremenog povlašćenog proizvođača prestaje da važi oduzimanjem, istekom ugovora o otkupu eletkrične energije, u slučaju stečaja i likvidacije, isticanjem roka važenja (kod privremenog povlašćenog proizvođača).

2. Uredba o podsticajnim merama za proizvodnju električne energije iz obnovljivih izvora $i$ iz visokoefikasne kombinovane proizvodnje električne i toplotne energije. Ovom uredbom se bliže propisuju podsticajne mere za proizvodnjuelektričneenergijeizobnovljivih izvora i iz visokoefikasne kombinovane proizvodnje električne i toplotne energije, uslove za njihovo ostvarivanje, trajanje podsticajnog perioda, prava i obaveze koje iz tih mera proizlaze za povlašćene proizvođače električne energije i druge energetske subjekte kao i druga pitanja u skladu sa zakonom (Ministarstvo rudarstva i energetike, 2016 a). Merama podsticaja (eng. Feed-in tariffs) su predviđene podsticajne otkupne cene po proizvedenom $\mathrm{kWh}$ iz OIE koje su usklađene sa tehnologijom koja se primenjuje i koje Vlada Republike Srbije propisuje na određeni vremenski period kako bi podstakla investitore i smanjila rizik investicije.

3. Uredba o ugovoru o otkupu električne energije $i$ model ugovora o otkupu električne energije. Privremenom povlašćenom proizvođaču električne energije je omogućeno da zaključi ugovor o otkupu električne energije sa kupcem pod uslovom da mu kasnije, u propisanom roku, bude odobren status povlašćenog proizvođača električne energije. To praktično znači da je raniji koncept Privremenog ugovora o otkupu električne energije, koji je predstavljao veliku neizvesnost za investitore, banke i druge finansijere, sada zamenjen novim konceptom Pojedinačnog ugovora o otkupu električne energije koji unosi više izvesnosti u poslovne procese.

Takođe, model ugovora o otkupu električne energije ("Službeni glasnik RS", broj 56/2016) je značajan doprinos koji za krajnji cilj, između ostalog, ima i uvođenje izvesnosti u celom procesu važnom za potencijalne investitore i finansijere. Ovim modelom ugovora, ugovorne strane uređuju uslove otkupa proizvedene električne energije u elektrani, kao i uslove i način korišćenja podsticajnih mera u vezi sa proizvedenom električnom energijom $\mathrm{u}$ elektrani na koje prodavac ima pravo $\mathrm{u}$ skladu sa Zakonom o energetici, propisima donetim na osnovu njega i ovim ugovorom.

Pored podsticajnih mera, podsticajnog perioda, obaveza prodavca i drugih tehničkih uslova koji moraju biti ispunjeni, model ugovora definiše i način obračuna i plaćanja, kao i instrumente obezbeđenja plaćanja. Ugovorne strane se modelom ugovora usaglašavaju da kupac preda prodavcu tri blanko menice sa klauzulom "bez protesta" i neograničenog važenja (bez datuma isteka), registrovanu kod Narodne banke Srbije zajedno sa meničnim ovlašćenjem i drugom dokumentacijom za korišćenje iste. Takođe, regulisan je i odnos kod zalaganja i ustupanja potraživanja prodavca, pri čemu kupac daje saglasnost prodavcu da može trećem licu dospeli i budući iznos bilo kog novčanog potraživanja koji stekne po osnovu ovog ugovora da ustupi u skladu sa zakonom kojim se uređuju obligacioni odnosi, odnosno da založi u skladu sa zakonom kojim se uređuje založno pravo na pokretnim stvarima i pravima. Pored samog modela ugovora, postojanje ovih važnih elemenata bitno i pozitivno deluje na predvidivost finansijskih tokova projekta, čime se omogućava afirmativno okruženje na dugi rok za potencijalne investitore $\mathrm{i}$ finanansijere.

4. Mehanizmi zaštite valute ugovora. Značaj navedenih uredbi i modela ugovora za potencijalne investitore i finansijere je $\mathrm{i}$ u tome što eliminišu nejasnoće koje kod projekata u ovoj oblasti dominiraju u domenu 
capacity of up to $30 \mathrm{MW}$ as well as biomass power plants, biogas, waste and geothermal power plants. The duration of the privileged producer status is indefinite. The status of a privileged producer and temporary privileged producer shall supersede the confiscation, the expiry of the contract on the purchase of electric energy, in the event of bankruptcy or liquidation, and the expiration date (for the temporary privileged producer).

2. Decree on incentives for production of electricity from renewable energy sources and high-efficiency combined production of electricity and heat. This Regulation explains in detail the incentives for production of electricity from renewable energy sources and high-efficiency combined production of electricity and heat, the conditions for their exercise, the duration of the incentive period, rights and obligations arising from these measures for privileged power producers and other energy entities and other issues in accordance with the law (Ministry of Mining and Energy, 2016 a). Incentives (feed-in tariffs) are provided for stimulating the purchase price per $\mathrm{kWh}$ produced from renewable energy sources that are compatible with the technology used, and the Government of the Republic of Serbia prescribes a certain period of time in order to encourage investors and reduce the risk of investment.

3. Regulation on the Contract for the purchase of electricity and the model contract for the purchase of electricity. A temporary privileged producer of electricity is able to conclude a contract on the purchase of electricity with the customers under the condition that later on, in due time, he will be granted the status of a privileged producer of electricity. This practically means that the earlier concept of the Interim agreement on purchase of electricity, which represented a major uncertainty for investors, banks and other financiers, is now being replaced by the new concept of an Individual Contract for the purchase of electricity in order to bring more certainty into the business processes. Also, the Model contract for the purchase of electricity ("Official Gazette of RS", No. $56 / 2016$ ) is a significant contribution to the ultimate goal which is, among other things, to introduce certainty into the whole process which is important for potential investors and financiers. With this model contract, the parties govern the conditions of purchase of the electricity produced in a power plant, as well as the conditions and manner of using the incentives related to the production of electrical energy in the power plant to which the seller is entitled in accordance with the Energy Law, the regulations made thereunder and under this model contract.

In addition to the incentives, the incentive period, the obligation of the seller and other technical conditions which must be fulfilled, the model contracts define the method of calculation and payment, as well as collaterals. The Contracting Parties shall conform to the model contract that the buyer would deliver to the seller three blank bills of exchange with the clause "without protest" and unlimited validity (no expiration date), registered with the National Bank of Serbia, together with the letter of authorization and other documentation for its use.

Also, the relation with the commitment and assignment of claims/receivables is regulated, whereby the buyer gives to the seller the consent that due amount of any cash receivables acquired under this agreement may be ceded to a third party, in accordance with the law governing obligations, or may be pledged in compliance with the law governing pledges on movable assets and rights. In addition to the model contract, the existence of these important

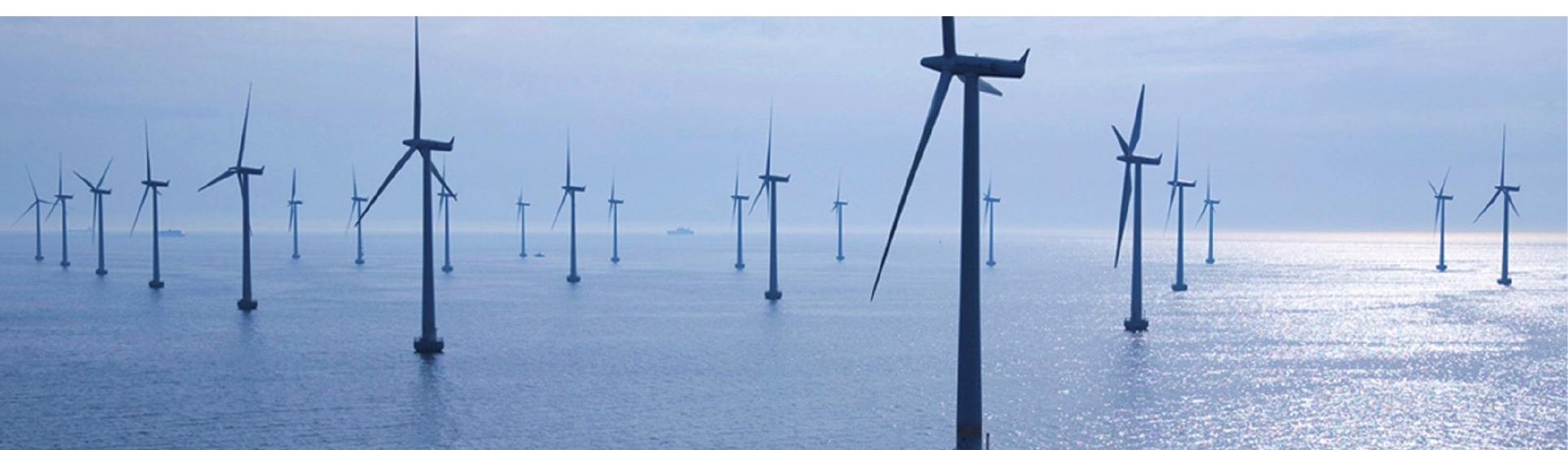


zaštite vrednosti valute. Tako se npr. kao valuta podsticajne otkupne cene Uredbom o podsticajnim merama za proizvodnju električne energije iz obnovljivih izvora i iz visokoefikasne kombinovane proizvodnje električne i toplotne energije definiše upotreba evrocenta po kilovat satu (c€/ $\mathrm{kWh}$ ) i zaokružuje se na dve decimale. Predviđena je i redovna godišnja korekcija podsticajnih otkupnih cena zbog inflacije $u$ evro zoni korišćenjem stope INFgod - kao izraza godišnje inflacije u evro zoni izražene u procentima koju je objavljuje Evropska kancelarija za statistiku (EUROSTAT).

5. Mogućnosti javno-privatnog partnerstva u oblasti OIE. OIE je oblast koja je u bliskoj vezi sa drugim segmentima koji na sličan način predstavljaju potencijal rasta ali i poslovnu mogućnost. Potrebe za finansiranjem istih, kao i mogućnost uvođenja novih finansijskih instrumenata, proizvoda i tehnika su već prisutne na domaćem tržištu sa tendencijom njihovog rasta u budućnosti. Važno je pomenuti mogućnosti Zakona o javno-privatnom partnerstvu i koncesijama, kao i Zakona o ulaganjima koji afirmativno utiču na oblast OIE tako što javnom sektoru daju mogućnost realizacije projekata od javnog značaja (kapitalnih investicija) angažovanjem sredstava, tehnologije, know-how i drugih kapaciteta privatnog sektora domaćeg ili stranog porekla. Do sada je u Srbiji od odobrenih 40 predloga projekata javno-privatnog partnerstva, pet u oblasti OIE (Komisija za javno-privatno partnerstvo, 2016) i to su:

- Predlog projekta javno-privatnog partnerstva JKP Gradska toplana Zrenjanin kojim se predlaže proizvodnja toplotne i električne energije iz biogasa, odnosno upotreba organskih sirovina poljoprivredne industrije kao i ostataka i nusproizvoda iz prehrambene industrije u njegovoj proizvodnji;

- Predlog koncesionog akta kojim se predlaže poveravanje poslova proizvodnje i distribucije toplotne energije na području opštine Batočina;

- Predlog projekta javno-privatnog partnerstva za poveravanje obavljanja komunalne delatnosti sakupljanja, transporta i odlaganja komunalnog otpada i proizvodnje i distribucije toplotne energije na teritoriji gradske opštine Grocka;

- Predlog projekta javno-privatnog partnerstva za proizvodnju toplotne i električne energije upotrebom obnovljivih izvora energije u opštini Vrbas;

- Predlog projekta javno-privatnog partnerstva JKP "Rasina" Brus kojim se predlaže izgradnja magistralnog cevovoda za snabdevanje vodom opštine Brus i izgradnja male hidroelektrane.

Iako je od ukupno 40 predloga projekata javno-privatnog partnerstva svega pet predloženo u oblasti OIE, to predstavlja indikator da su razvojne potrebe na nivou lokalne samouprave u Srbiji vrlo vidljivo $\mathrm{i}$ jasno prisutne $\mathrm{u}$ domenu OIE. Imajući u vidu da se primena ovog koncepta u Srbiji još uvek nalazi u početnoj fazi i da ima više od 145 lokalnih samouprava, postoje očekivanja da će ovaj koncept finansiranja biti sve češće primenjivan a samim time i projekti iz oblasti OIE zastupljeniji.

6. Značaj finansijske podrške od strane države. Direktna podsticajna podrška države igra značajnu ulogu u omogućavanju pokretanja čitavog lanca mogućih poslovnih transakcija u domenu OIE. Tako npr. u toku jula 2016. godine, potpisani su ugovori o dodeli bespovratnih sredstava za podršku izgradnji šest postrojenja za kombinovanu proizvodnju električne i toplotne energije iz biomase i biogasa, pa će državna subvencija iznositi 1,6 milona dolara. Ukupna vrednost tih postrojenja je 22,7 miliona evra, a njihovom izgradnjom Srbija će dobiti kapacitete od ukupno 6,32 MW instalisane električne snage postrojenja koja koriste obnovljive i lokalno dostupne izvore energije. Bespovratna sredstva su dodeljena u iznosu od 15 odsto ukupne investicione vrednosti svakog pojedinačnog projekta, odnosno maksimalno 275.000 dolara, pod uslovom da je ukupna investiciona vrednost pojedinačnog projekta veća od 1,2 miliona dolara. Ugovorima se predviđa isplata 30 odsto ukupno dodeljenog novca, dok će preostalih 70 odsto biti isplaćeno tek nakon realizacije ukupne investicije i priključenja 
elements is essential and has a positive effect on the predictability of financial flows of the project, allowing affirmative environment in the long term for potential investors and financiers.

4. Mechanisms for the protection of the contract's currency. The importance of the above Regulation and the model contract for potential investors and financiers is that it eliminates uncertainty that the projects in this field are burdened with when it comes to the protection of the currency value. Thus, for example, the Decree on incentives for production of electricity from renewable energy sources and high-efficiency combined production of electricity and heat defines the use of cents per kilowatt hour ( $€$ / kWh) as the currency of incentive purchase price and it is rounded up to two decimal places, providing for the regular annual correction of incentive purchase price inflation in the euro area using INFgod rates - as an expression of the annual inflation in the euro zone as a percentage and published by the European Statistical office (EUROSTAT).

5. Opportunities for Public-Private Partnership in the field of RES. RES is an area that is closely related to other segments which similarly represent the growth potential but also a business opportunity. Financing needs, as well as the possibility of introducing new financial instruments, products and techniques are already present on the domestic market with the tendency of their growth in the future. It is important to mention the possibility of the Law on PublicPrivate Partnerships and Concessions, as well as the Law on Investments which have an affirmative impact on the field of renewable energy by offering the public sector an opportunity for the realization of projects of public interest (capital investment), engaging resources, technology, know-how and other capacities of the private sector, of domestic or foreign origin. So far, among the 40 PublicPrivate Partnership projects proposals approved in Serbia, there are five in the field of RES (the Commission for Public-Private Partnership, 2016):

- Proposal of a Public-Private Partnership of PUC City Heating Plant Zrenjanin proposing the production of heat and electricity from biogas, and the use of organic raw materials and agricultural industry residues and by-products from the food industry for its production;

- Draft Concession Act which proposes the delegation of tasks of production and distribution of thermal energy in the municipality of Batočina;

- Proposal of a Public-Private Partnership for delegating the performance of utility activities of collection, transport and disposal of municipal waste and the production and distribution of thermal energy in the municipality of Grocka;

- Proposal of a Public-Private Partnership for the production of heat and electricity using renewable energy sources in the municipality of Vrbas;

- Proposal of a Public-Private Partnership of JKP "Rasina" Brus proposing the construction of the main pipeline for water supply of the municipality Brus and construction of a small hydropower plant.

Although only five out of the total of 40 project proposals of Public-Private Partnership are in the field of renewable energy, this is an indicator that the development needs at the local level in Serbia are very visible and clearly present in the domain of renewable energy. Bearing in mind that the application of this concept in Serbia is still at an early stage and that in Serbia there are about 145 local governments, there are expectations that this concept of financing will be increasingly applied and projects in the RES field more frequent.

6. The importance of financial support by government incentives. The direct support from the state plays a significant role in enabling the launch of the whole chain of possible business transactions in the field of renewable energy. Thus, for instance, in July 2016, the grant agreements were signed to support the construction of six plants for combined production of electricity and heat from biomass and biogas, with the state subsidy amounting to 1.6 million dollars. The total value of these plants is 22.7 million, and after their construction, Serbia will get a 
postrojenja na distributivnu mrežu. Ugovori sa šest investitora koji će izgraditi postrojenja potvrđuju stratešku opredeljenost države za podizanje učešća obnovljivih izvora energije i potrebu da Srbija krupnim koracima ide u pravcu stabilnog energetskog sistema, gde će se odgovorno koristit ugalj, ali i energija vetra, biomase i biogasa (Ministarstvo rudarstva i energetike, 2016b).

Pored ovog, postoje i drugi primeri dobrih inicijativa i saradnje u oblasti OIE čiji je cilj unapređenje razvoja ovog tržišta. Neki od njih su Kreditna linija Nemačke razvojne banke KfW za projekte energetske efikasnosti i obnovljivih izvora energije (tzv. 4 e program) koji sprovodi Ministarstvo rudarstva i energetike i koja je usmerena na finansijski/bankarski sektor $\mathrm{u}$ cilju blagovremenog informisanja banaka o mogućnostima finansiranja ovih projekata, različiti projekti u okviru programa podrške Nemačke razvojne agencije GIZ u Srbiji u oblasti energetike itd. Takođe, preduzeće "Bioelektra" iz Botoša izgradilo je pogon za proizvodnju električne i toplotne energije iz biogasa na bazi biomase različitog porekla, a investicija koja je u prvoj fazi vredna oko 2,5 miliona evra, prepoznata je kao izuzetno značajan poduhvat koji je finansiran kreditom Erste banke u iznosu od 1,2 miliona evra, a potom je dobio i podršku holandske vlade $\mathrm{u}$ vidu bespovratne subvencije od 688.000 evra. Projekat je nedavno dobio i podršku od 275 hiljada dolara iz sredstava obezbeđenih u okviru projekta "Smanjenje barijera za ubrzani razvoj tržišta biomase u Srbiji", koji finansira Globalni fond za zaštitu životne sredine, a sprovodi UNDP u partnerstvu sa Ministarstvom rudarstva i energetike (Ministarstvo rudarstva i energetike, 2016b).

Inače, i u Evropskoj uniji postoji više izvora, načina i formi finansijske podrške za projekte obnovljivih izvora energije, baš kao što je to slučaj sa projektima energetske efikasnosti (Sredojević, 2016). U skladu sa time, podsticajne mere $i$ oblici koji su na snazi u Republici Srbiji potpuno korespondiraju odnosnim prilikama u EU.

\section{Analiza izazova $u$ finansiranju OIE projekata}

Oblast OIE iako perspektivna, nije dovoljno iskorišćena. Postoji niz segmenata u kojima leže faktori koji mogu stimulativno uticati na dalje jačanje ovog tržišta u Srbiji, a neke od njih koji najdirektnije utiču na potencijale finansiranja su istaknute $u$ daljem nastavku rada.

\section{Specifični oblici finansiranja kod OIE projekata i zahtevi tržišta}

Ukupni troškovi projekata koji se oslanjaju na tehnologije obnovljivih izvora energije su u značajnom stepenu osetljivi na uslove finansiranja. Postoje dva osnovna načina finansiranja projekata u sektoru energetike: projektno finansiranje i korporativno finansiranje. Tržište obnovljivihizvora energijeu velikoj meri se oslanja na projektno finansiranje. U ovim aranžmanima, kreditori posmatraju najpre tokove gotovine i imovinu određenog projekta za otplatu umesto imovinu, sredstva ili kredit investitora objekta kao pravnog lica. Neophodni element kod ovakvog oblika finansiranja, naročito kod kapitalno-intenzivnih tehnologija kao što su projekti obnovljivih izvora energije, predstavljaju dugoročni ugovori o kupovini/otkupu električne energije jer pružaju relativno siguran priliv prihoda. Iako imaju veliki potencijal i atraktivnost na tržištu, projekti obnovljivih izvora energije se nalaze u manje povoljnom položaju u procesu finansiranja $\mathrm{u}$ odnosu na druge proizvodne tehnologije, zbog percepcije rizika resursa i tehnologije i male veličine projekta i industrije (Wiser and Pickle, 1997, xiv).

Kod projektnog finansiranja, kao tehnike finansiranja koja se koristi kod projekata EE I OIE, kvalitetna projekcija očekivanih novčanih tokova sa jedne strane i procena rizičnosti (koji mogu umanjiti očekivane novčane tokove projekta) sa druge strane je od velike važnosti. Dakle, u fokusu pažnje je sam projekat i ocena njegove rentabilnosti i rizičnosti. Nakon identifikacije rizika, pokušava se preduprediti njihov nastanak i traži mogućnost njihovog umanjenja ako nastanu, dok se deo rizika koji nije moguće ublažiti, obično ugrađuje u cenu kapitala.

Rentabilnost projekta je najvažnija, i ona se postiže nizom pokazatelja koji kvantitativno mere odnose između očekivanih učinaka i ulaganja i baziraju se na podacima dobijenih iz prethodnih analiza projekta. Ona je verovatno dokazana već u prethodnim fazama 
total capacity of $6.32 \mathrm{MW}$ of installed electric power plants that are using renewable and locally available sources of energy. The grants are awarded in the amount of 15 percent of the total investment value of each project, and up to a maximum of $\$ 275,000$, under the condition that the total investment value of individual project is more than 1.2 million dollars. The treaties provide advance payment of 30 percent of the allocated money, while the remaining 70 percent is to be paid only after the implementation of the total investment and connection of the plant to the distribution network. The contracts with six investors that will build the plant confirmed the strategic commitment of the state to raise the share of renewable energy sources and the need for Serbia to go straight towards a stable energy system, with a responsible usage of coal and wind energy, biomass and biogas (Ministry of Mining and Energy, 2016b).

In addition to this, there are other examples of good initiatives and cooperation in the field of renewable energy aimed at improving the development of this market. Some of them are the project credit line of the German Development Bank KfW for energy efficiency and renewable energy sources (i.e. 4 E program) implemented by the Ministry of Mining and Energy, and which focuses on the financial/banking sector in order to exchange timely information with the banks about the possibilities of financing these projects, the various projects under the support program of the German Development Agency GIZ in Serbia in the field of energy and so on. Also, the Company "Bioelektra " from Botoš built a plant for the production of electricity and heat from biogas based on biomass of various origins, with an investment, worth about 2.5 million EUR in the first phase, which has been recognized as a very significant undertaking funded by the Erste Bank loan in the amount of 1.2 million EUR, and then supported by the Dutch government in the form of non-repayable grants of 688,000 EUR. The project has recently received the support of 275 thousand dollars from the funds provided under the project "Reducing barriers for rapid biomass market development in Serbia", financed by the Global Fund for Environmental Protection and implemented by UNDP in partnership with the Ministry of Mining and Energy " (Ministry of Mining and Energy, 2016b).

Otherwise, there are several sources, methods and forms of financial support for renewable energy projects in the European Union, as it is the case with energy efficiency projects (Sredojević, 2016). Accordingly, incentives and forms which are in force in the Republic of Serbia fully correspond to the respective conditions in the EU.

\section{Analysis of the challenges in RES projects financing}

Although promising, the field of OIE is not sufficiently used. There are number of segments which contain the stimulating factors that can influence the further strengthening of the market in Serbia, and some of them which directly affect the potential funding are highlighted in the subsequent sections of the paper.

\section{Specific forms of financing RES projects and the market conditions}

The total costs of projects that rely on renewable energy technologies are rather sensitive to financing conditions. There are two basic ways of financing projects in the energy sector: project finance and corporate finance. Renewable energy market largely relies on project financing. In these arrangements, lenders observe first the cash flow and assets to repay a specific project instead of the property, assets or credit facility of investors as a legal entity. The essential elements in this form of financing, especially in capital-intensive technologies such as renewable energy projects, are the long-term contracts on the purchase 
ekonomske opravdanosti projekta, kroz studiju izvodljivosti, a ocenjuje se kroz nekoliko kriterijuma rentabilnosti:

1. Neto sadašnja vrednost projekta (NPV), koja svakako mora biti veća od nule, tj. pokazuje koliko nove vrednosti je projekat stvorio nakon podmirenja svih obaveza (uključujući i kreditora), odnosno kolika je sposobnost projekta da vrati uložena sredstva. Utvrđuje se na bazi projekcije novčanih tokova projekta za ceo životni vek, i diskontovanjem se svodi na sadašnju vrednost.

2. Interna stopa prinosa (IRR) koja mora biti veća od diskontne stope ili kamatne stope na dugoročne kredite (zahtevana stopa prinosa na kapital ili cena kapitala, određuje se putem više metoda).

3. Racio koristi-troškovi (BCR) koji mora biti veći od 1.

4. Likvidnost, kao dinamički i funkcionalni pokazatelj rentabilnosti - sposobnost da se u svakom momentu podmire obaveze projekta, tj. da je finansijski tok projekta dobar.

5. Prag rentabilnosti - takođe dinamički i funkcionalni pokazatelj rentabilnosti. Važno je da projekat dostigne ili ima svoj prag rentabilnosti, a to je minimalna iskorišćenost pri kojoj je projekat rentabilan, tj. obim njegove iskorišćenosti koji omogućava da prihodi pokriju fiksne, varijabilne i troškove finansiranja.

Rentabilnost projekta nije moguće izračunati na današnji dan, i izmeriti je kroz vreme kao konstantu, jer ona zavisi od raznih varijabli projekta. Zato je važno uraditi analizu osetljivosti - promenu ključnih varijabli projekta i ocenu njihovog uticaja na rentabilnost projekta (Stojanovski, 2009, 44). Radi se simulacija promena nekoliko varijabli pojedinačno ili istovremeno (rast cene inputa, pad cene autputa, rast diskotne stope, rast fiksnih rashoda), njihov efekat na neto sadašnju vrednost (koja opada ili raste), kao i na internu stopu prinosa (koja onda posledično raste ili opada). Ukoliko u nekom od scenarija pokazatelji rentabilnosti padnu ispod zahtevanog minimuma, onda to znači da projekat nije rentabilan u slučaju da se pojavi ta grupa rizika, pa se dalje radi na elaboraciji toga da se ti rizici eliminišu ili smanji njihov uticaj.

Kada je reč o faktorima koji utiču na rentabilnost projekta, za kreditora i za privatnog partnera (direktno), kao i za javnog (indirektno) najveći rizici su stoga: nezavršetak projekta na vreme, nezavršetak projekta $u$ planiranom obimu sredstava, neiskorišćenost kapaciteta, nedovoljni prihodi, rizik skraćivanja ekonomskog veka projekta. Ovi stalno prisutni rizici rentabilnosti daleko prevazilaze pitanje izbora valute.

Pored gore navedenih faktora koji utiču na rentabilnost datog projekta, treba imati $u$ vidu i faktore koji utiču na vrednost novca tokom životnog veka projekta, bez obzira na valutu koja se koristi kao što su: inflacija, oportunitetni trošak (izgubljena korist od neke alternativne investicije), činjenica da novacima veću vrednost u sadašnjosti nego u neizvesnoj budućnosti. Drugim rečiima, najveći rizici u ovom aspektu su: rizik inflacije i valutni rizik (rizik promene deviznog kursa), uz delimični rizik kamatnih stopa. Ovi rizici tangiraju projekat prvenstveno, a potom i pozicije partnera. Bilo koja valuta da se izabere, oni postoje, i njih nije moguće eliminisati. Oni se mogu smanjiti i može se izabrati opcija koja na dati projekat ima manje loš uticaj na dugi rok od opcije koja ima više loših efekata tokom vremena.

Kada je reč o uslovima finansiranja na tržištu projektnog finansiranja u Srbiji, preovladava uverenje da su ekonomsko pravni rizici vezani za poslovanje u Srbiji još uvek na nivou iznad prosečnih da bi se više ulagalo $u$ formi projektnog finansiranja inače, a samim tim i u projektno finansiranje projekata obnovljivih izvora energije. Neki od najčešćih razloga koji se nalaze na nivou samog projekta, a koji nepovoljno utiču na bankabilnost projekta su:

- Tehnički aspekt projekta neodgovarajući ili sa nedovoljno afirmativnim uticajem na bankabilnost projekta

- Finansijski pokazatelji projekta nisu zadovoljavajući, kao npr. previše dug vremenski period potreban za povrat investicije, interna stopa rentabilnosti, investicioni i operativni troškovi, neto sadašnja vrednost očekivane dobiti isl

- Tržište nabavke - nemogućnost obezbeđenja dugoročnih aranžmana za nabavku inputa (biomasa, npr)

- Stabilnost prihoda - nemogućnost obezbeđenja dugoročnih prihoda. 
of electricity because they provide a relatively secure revenue stream. Although they have a great potential and attractiveness of the market, renewable energy projects are in a less favorable position in the process of funding compared to other production technologies, because of the perceived risk of resources and technology, small size of the project, and the small size of the industry (Wiser and Pickle, 1997, xiv).

In project financing, as a financing technique used in Energy Efficiency and RES fields, the high quality projection of expected cash flows on the one hand and risk assessment (which may reduce the expected cash flows of the project) on the other hand are of great importance. Therefore, the focus of the attention is the project itself and the estimate of its cost-effectiveness and risks. After identifying the risks, the next step is focused on trying to prevent their formation and seeking the possibility of their mitigation, if occurred, while the part of the risks that cannot be mitigated, usually gets built into the cost of capital. The economic justification or profitability of the project is most important, and it is achieved by a series of indicators that quantitatively measure the relationships between the expected effects and investment and are based on the data obtained from the previous analysis of the project.

Profitability was probably already demonstrated in the previous stages of the economic feasibility of the project through a feasibility study that estimates the costeffectiveness based on the several criteria:

1. Net present value (NPV), which certainly must be greater than zero, i.e. shows which new value the project created after the settlement of all liabilities (including creditors), or what is the ability of the project to return the invested funds. It should be determined on the basis of cash flow projections for the project lifetime, and discounted to the present value.

2. The internal rate of return (IRR), which must be higher than the discount rate, or the interest rate on long-term loans (the required rate of return on capital or equity is determined by multiple methods).

3. The benefit-cost ratio (BCR), which must be greater than 1.

4. Liquidity, as a dynamic and functional indicator of profitability - the ability to settle the obligations of the project at any point, i.e. the indicator that the financial flow of the project is good.

5. The threshold of profitability - is also a dynamic and functional indicator of profitability. It is important that the project has reached or has a break-even point, which is the minimum utilization at which the project is profitable, i.e. the extent of its usage that allows covering the fixed-income, variable and financing costs.

The profitability of the project cannot be calculated at this day or measured over time as a constant, because it depends on different variables of the project. Therefore, it is important to apply a sensitivity analysis - by changing the key variables of the project and by assessing their impact on the profitability of the project (Stojanovski, 2009, 44). This is a simulation of changes in several variables individually or simultaneously (increase input prices, the decline in output prices, the growth of discount rates, growth of fixed expenses), their effect on the net present value (which decreases or increases), and the internal rate of return (which it subsequently increases or decreases). If, under any of the scenarios, profitability indicators fall below the required minimum, it means that the project is not cost-effective in case that this group of risks happens, so that the further analysis should be focused on eliminating these risks and reducing the consequences of their occurrence.

Talking about the factors affecting the profitability of the project, which have a direct impact on the creditors and the private partner, and an indirect impact on the public partner, the highest risks are therefore: non-completion of the project on time, non-completion of the project within the planned budget, underutilized capacity, insufficient income, and the risk of shortening the economic life of the project. These ever-present risks of profitability are completely unrelated to the matter of the choice of currency.

In addition to the above factors affecting the profitability of a given project, one should also take into account the factors that influence the value of money over the life of the project, regardless of the currency used, such as 
Pored ovih, postoje i razlozi na nivou tržišta koji utiču na relativno nisku tražnju za finansiranjem ovih projekata, od kojih je najprisutniji opšti nivo rizika vezanih za projektno finansiranje $\mathrm{u}$ zemlji uopšte, $\mathrm{i}$ posebno za projekte OIE. Ostali rizici iz grupe najznačajnijih na nivou tržišta ili okruženja opisani su u nastavku dole.

\section{Vremenska ograničenost važenja regulative koja definiše podsticajne mere za korišćenje OIE}

Vremenska ograničenost važenja regulative koja definiše podsticajne mere za korišćenje OIE - Uredba koja definiše podsticajne mere za proizvodnju električne energije iz obnovljivih izvora i iz visokoefikasne kombinovane proizvodnje električne i toplotne energije je vremenski ograničena što u praksi izaziva različite posledice, od kojih je najveća i za investitore najnepovoljnija - neizvesnost uslova koji će da važe po njenom isteku. Dodatni problem nastaje i ukoliko nakon isteka važnosti uredbe nije blagovremeno aktivirana nova uredba sa novim pravilima; u takvim situacijama povlašćeni proizvođači mogu ili potpisivati komercijalne ugovore sa EPS Snabdevanje prema kojima se proizvedeni kWh plaća po tržišnoj ceni ili čekati da se nova uredba usvoji, a u međuvremenu proizvoditi električnu energiju bez ikakve naknade. Neretko, u ovakvim slučajevima banke sa postojećim klijentima imaju velikih problema zato što klijenti, ne svojom krivicom, nisu u mogućnosti da servisiraju obaveze prema banci a banka mora već nekoliko meseci retroaktivno da koriguje uslove kreditiranja. Štaviše, kada je reč o budućim potencijalnim projektima, banke do daljnjeg stopiraju razmatranje finansiranja novih projekata iz oblasti OIE zbog ovakve nepredvidivosti uslova poslovanja koja, u značajnoj meri, utiče na troškove, rizike i cenu finansiranja ovih projekata.

\section{Uticaj troškova naknada za korišćenje državnog zemljišta i vode na isplativost projekata OIE}

Troškovi naknada za korišćenje vodnog, šumskog i železničkog državnog zemljišta (JVP Srbijavode / JVP Vojvodinavode, JP Srbijašume, JP Železnice Srbije, JP Putevi Srbije) imaju značajan uticaj na operativne troškove rada elektrana koje koriste OIE, prvenstveno mini hidroelektrana, kako u pogledu visine iznosa, tako i dinamike naplate - jedino kod puteva naknada se plaća jednokratno, dok kod drugih vidova naknada se plaća redovno mesečno ili godišnje. Posebno u slučaju objekata malih instalisanih snaga sa linijskom infrastrukturom (npr. hidrolektrane instalisane snage ispod $1 \mathrm{MW}$ ) taj uticaj se kreće i do $9 \%$ godišnjeg prihoda projekta što može dovesti do ekonomske neopravdanosti izgradnje takvih elektrana i do odustajanja investitora od izgradnje i/ili banaka od njihovog finansiranja, uprkos postojanju garantovanih otkupnih cena proizvedene električne energije.

Pored visine i dinamike - učestalosti plaćanja, postoje i dodatni problemi, kao npr. kada je u pitanju naknada za šume. Na JP Srbijašume pozitivnim propisima nisu preneta javna ovlašćena za odlučivanje o upravnim stvarima i upravnom postupku u oblasti energetike, odnosno izgradnje za korišćenje OIE i nema zakonskih mogućnosti za ustanovljavanje prava stvarne službenosti.

Takođe, investitorima je kao i u slučaju uredbi o podsticajnim merama za koršćenje OIE, veoma važna predvidivost i transparentnost visine ovih naknada. Jedino je cenovnik JVP Srbijavode javno objavljen, dok se cenovnici Srbijašume menjaju svake godine, a cenovnici JP Železnice Srbije i JP Putevi Srbije se nisu menjali od 2010 i 2008 godine. Poseban problem za investitore i finansijere predstavlja što se ove naknade mogu promeniti i nakon odobrenja kredita.

\section{Institucionalna $\mathrm{i}$ administrativna ograničenja}

Postoje institucionalna i administrativna ograničenja kao što su rešavanje imovinskopravnih odnosa, politika poreza, tarifa i naknada, nepostojanje adekvatnog kapaciteta na nivou lokalnih samouprava, neusklađenost propisa, i sl. Još jedno u ovoj grupi ograničenja su i zahtevi da investitori finansiraju izradu detaljnih regulacionih planova ili urbanističkih projekata usled toga što mini hidroelektrane često nisu obuhvaćene postojećim prostorno planskim aktima ili su obuhvaćene, ali nadležan organ za izdavanje lokacijskih dozvola zahteva 
inflation, the opportunity cost (lost benefit of some alternative investments), the fact that money has a greater value in the present than in the uncertain future. In other words, the biggest risks in this regard are: the risk of inflation and currency risk (risk of changes in the exchange rates), with a partial interest rate risk. These risks primarily affect the project, and then the position of partners. They exist and apply regardless of the currency, and they cannot be eliminated. They can be reduced, and one can choose the option which will affect the project in a less adverse way in the long run instead of the option that will have more adverse effects over time.

In terms of the financing conditions in the project financing market in Serbia, there is a prevailing belief that the commercial legal risks associated with doing business in Serbia are still at a level above the average, thus preventing the increase of this form of financing and, in turn, the project financing of renewable energy projects. Some of the most common reasons that are at the level of the project, which adversely affect the bankability of the project, are:

- The technical aspect of the project has inadequate or insufficient affirmative impact on the bankability of the project;

- Financial indicators of the project are not satisfactory, such as a very long period of time required for return on investment, internal rate of return, investment and operating costs, the net present value of expected profits, etc.

- Procurement market - the impossibility of providing long-term arrangements for the purchase of inputs (biomass, for example);

- Revenue stability - the impossibility of providing long-term income.

In addition to these, there are also reasons at the level of the market which affect a relatively low demand for financing these projects, among which is the level of risk related to project financing in the country in general, and especially for renewable energy projects. Other risks, impacting most significantly the level of the market and the environment are described below.

\section{Time limit in validity of the legislation} which defines the incentives for RES usage

The regulation defining incentives for the production of electricity from renewable energy sources and of high-efficiency co-generation of electricity and heat is time limited in practice and causes a variety of effects, one of which is the largest and for investors the least favorable - the uncertainty of conditions that will apply upon its expiration. An additional problem arises if, after the expiry of the regulation, a new regulation with the new rules is not timely activated; in such situations privileged producers can either sign commercial contracts with EPS Supply according to which the produced $\mathrm{kWh}$ is paid at the market price, or wait for the new regulation to be adopted, while in the meantime the production of electricity is without any charge. Often, in such cases, banks have major problems with the existing clients because the customers, not through their own fault, are unable to service their obligations to the bank and therefore the bank must adjust the credit conditions several months retroactively. Moreover, when it comes to the future potential projects, the banks halt further consideration of financing the new projects in the field of renewable energy because of this unpredictability of business conditions that significantly affects the costs, risks and cost of financing of these projects.

\section{Impact of the cost of fees for the use of state land and water on the profitability of RES projects}

The fees for using water, forest and railway state land (Srbijavode/JVP Vojvodinavode, Srbijašume, Serbian Railways, PE Roads of Serbia) have a significant impact on operating

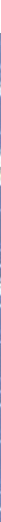


izradu odgovarajućeg urbanističkog projekta radi razrade lokacije.

\section{Zaključci i preporuke}

Analizirajući regulativu u oblasti OIE kojom se definišu i preduslovi finansiranja ovakvih projekata, zaključuje se da postoji kompleksan zakonski i institucionalni okvir koji predstavlja preduslov za sprovođenje projekata OIE. Razni raniji koncepti u oblasti OIE (Privremeni ugovor o otkupu električne energije, npr) koji su predstavljali veliku neizvesnost za investitore, banke i druge finansijere, $\mathrm{u}$ novom setu regulative zamenjeni su novim konceptima koji unose više izvesnosti $\mathrm{u}$ poslovne procese. $\mathrm{U}$ tom smislu je važno istaći i postojanje mera podsticaja (eng. Feed-in tariffs) koje Vlada Republike Srbije propisuje na određeni vremenski period kako bi podstakla investitore i smanjila rizik investicije. Postojanje samog modela ugovora o otkupu električne energije, uključujući i način obračuna i plaćanja, kao i instrumente obezbeđenja plaćanja kao njegovih važnih elemenata koji omogućavaju ugovornim stranama uzajamnu sigurnost $\mathrm{u}$ transakciji, bitno i pozitivno deluju na predvidivost finansijskih tokova projekta. Svim ovim pobrojanim mehanizmima se omogućava afirmativno okruženje na dugi rok za potencijalne investitore i finanansijere.

Međutim, potencijal ovog tržišta još nije dovoljno iskorišćen usled postojanja brojnih ograničenja koji imaju različito poreklo. Sa jedne strane je relativno nizak nivo svesti i edukacije o uslovima finansiranja ovakvih projekata, o čemu svedoči i još uvek prilično mali broj firmi sa iskustvom u analizi i projektovanju postrojenja na OIE u Srbiji. Sa druge strane su ograničenja koja su u vezi sa regulativom, neusklađenošću propisa, odlikama samog projekta, što povratno utiče na uslove finansiranja banaka prisutnih na tržištu. Dakle, postoje paralelni procesi u kojima se rešavanje nekih od navedenih prepreka daljem rastu tržišta OIE odvija paralelno sa perspektivama, mogućnostima i prilikama koje se svakodnevno realizuju. Postoje očekivanja da

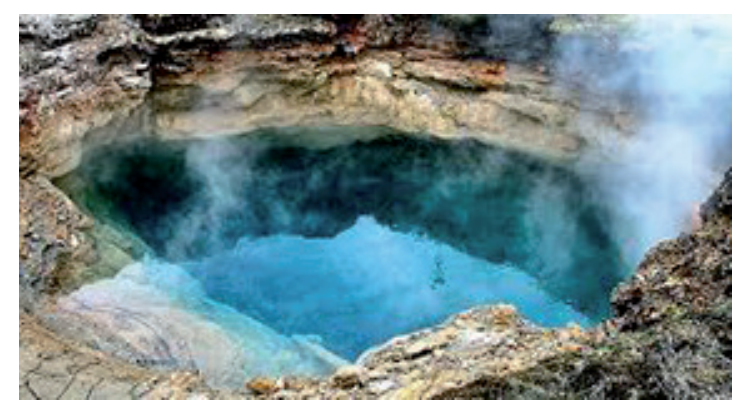

će se problemi ovog tipa prevazići realizacijom aktivnosti koje su usmerene na podizanje svesti šire društvene zajednice o značaju projekata OIE, odnosno uspostavljanjem vidljivijih i snažnijih mehanizama tržišta energetskih usluga u domenu OIE. U tom smislu, značajna bi bila i bliža saradnja između javnog sektora i potencijalnih investitora, kao i aktivna promocija investicionih mogućnosti u sektoru obnovljivih izvora energije.

Projekti OIE predstavljaju i veliki potencijal za same banke, kod kojih ovi poslovi tangiraju i sektor privrede i sektor stanovništva. Nesumnjivo je da gore analizirana regulativa $\mathrm{u}$ oblasti OIE predstavlja potrebnu, ali ne i dovoljnu osnovu za veće angažovanje banaka koje već imaju i banaka koje planiraju uvođenje kreditnih linija namenjenih sektoru OIE. Kvalitet predloga samog projekta, njegova rentabilnost i kapacitet nosilaca, u značajnoj meri određuju i stepen rizika kod procene mogućnosti finansiranja banaka. Kada je reč o uslovima finansiranja na tržištu projektnog finansiranja u Srbiji, preovladava uverenje da su ekonomsko pravni rizici vezani za poslovanje u Srbiji još uvek na nivou iznad prosečnih da bi se više ulagalo u projektna finansiranja inače, a samim tim i u projektno finansiranje projekata obnovljivih izvora energije. Ništa manje značajni su i rizici na nivou samog tržišta OIE u Republici Srbiji. Dobra komunikacija i saradnja koja postoji između Ministarstva rudarstva i energetike, banaka kao sadašnjih i potencijalnih finansijera, investitora i drugih zainteresovanih strana svakako predstavlja faktor koji afirmativno deluje na dalje unapređenje kvaliteta i dubine tržišta finansiranja projekata OIE u Republici Srbiji. 
costs of power plants that use renewable energy, especially mini hydro power plants, both in terms of the amount, and the dynamics of charge - the road fee is paid only once, while other forms of compensation are to be paid regularly monthly or annually. This impact, especially in the case of objects with low installed power to the line infrastructure (e.g. hydropower plants with installed capacity below $1 \mathrm{MW}$ ) where that impact can grow up to $9 \%$ of the turnover of the project, which could reversely lead to the questioning of the economic justification of the construction of such plants and eventually to the withdrawal of investors from the construction and/or banks from their funding, despite the existence of guaranteed purchase prices of the generated electricity.

In addition to the amount and frequency of payments, there are additional problems, such as the compensation for the forest. Srbijašume as a Public Company has not been granted the public authorization in the form of applicable regulations to decide on administrative matters and administrative proceedings in the field of energy, and construction for the use of renewable energy and there are no legal options for the establishment of the real easement rights.

Also, as in the case of the Regulation on incentives for using RES, very important for investors are the predictability and transparency of the height of these benefits. Only the price list of the Public Company Srbijavode has been made public, while the price lists of Srbijašume change every year, and the price lists of Serbian Railways, PE Roads of Serbia have not changed since 2010 and 2008 respectively. A particular problem for investors and financiers is that these fees may change even after the approval of the credit line.

\section{Institutional and administrative restrictions}

There are institutional and administrative restrictions such as solving property and legal issues, tax policy, tariffs and fees, the absence of adequate capacity at the local level, noncompliance of regulations, etc. Also in this group are restrictions and requirements imposed on investors to finance the creation of detailed regulation plans or urban projects due to the fact that small hydropower plants are often not covered by the existing spatial planning acts or if they are covered, the competent authority for issuing location permits requires the relevant urban project to work out the location.

\section{Conclusions and recommendations}

Analyzing the regulations in the field of renewable energy, which define the preconditions of financing such projects, we have concluded that there is a complex legal and institutional framework, which serves as a prerequisite for the implementation of RES projects. The various earlier concepts in the field of renewable energy (Temporary contract for the purchase of electricity, for example) which caused major uncertainties for investors, banks and other financiers, have been replaced by the new set of regulations and by new concepts bringing more certainty to the business processes. In this respect, it is important to stress the existence of incentive measures (feed-in tariffs) that the Government of the Republic of Serbia prescribes for a certain period of time in order to encourage investors and reduce the risk of the investment. The existence of the model contract for the purchase of electricity, including the method of calculation and payment, as well as collaterals as its important elements provide mutual security to the contracting parties in a transaction, and have a significantly positive effect on the predictability of financial flows of the project. All the listed mechanisms allow for an affirmative environment in the long term for potential investors and financiers.

However, the potential of this market has not yet been sufficiently utilized due to the existence of numerous restrictions of different origins. On the one side, the relatively low level of awareness and education about the terms of financing these projects, as evidenced by a still fairly small number of companies with the experience in the analysis and design of plants for renewable energy in Serbia. On the other hand, the limitations related to the regulation, the lack of harmonized rules, the characteristics of the project, which in turn affect the financing conditions of banks on the market. Thus, there are parallel processes at the same time, i.e. the process of resolving some of these obstacles to further the growth of the OIE markets takes place in parallel with the perspectives, 


\section{Literatura / References}

1. Evropska komisija. 2009. Directive 2009/28/ EC of the European Parliament and of the Council of 23 April 2009 on the promotion of the use of energy from renewable sources and amending and subsequently repealing Directives 2001/77/EC and 2003/30/EC. http://eur-lex. europa.eu/legal-content/EN/ TXT/HTML/?uri=CELEX:32009L0028\&from =EN. Pristup 30.09.2016.

2. Komisija za javno-privatno partnerstvo. 2016. Mišljenja Komisije. http://www. ppp.gov.rs/misljenja-komisije. Pristup 20.11.2016.

3. Ministarstvo rudarstva i energetike. 2016a. Uredba o podsticajnim merama za proizvodnju električne energije iz obnovljivih izvora i iz visokoefikasne kombinovane proizvodnje električne $i$ toplotne energije. Službeni glasnik RS, broj 56/2016.

4. Ministarstvo rudarstva i energetike. 2014. Zakon o energetici. Službeni glasnik RS, broj 145/14.

5. Ministarstvo rudarstva i energetike. 2016b. Ministar rudarstva i energetike otvorio međunarodne sajmove energetike i zaštite životne sredine. http://www.mre.gov.rs/ aktuelno.php\#a126. Pristup 24.10.2016.
6. Obnovljivi izvori energije. 2016. http:// obnovljiviizvorienergije.rs/. Pristup 03.10.2016.

7. Ryan Wiser and Steven Pickle. 1997. Financing Investments in Renewable Energy: The Role of Policy Design and Restructuring. Berkeley: University of California.

8. Savet stranih investitora. 2015. Bela knjiga 2015. Beograd: Savet stranih investitora.

9. Sredojević, S. 2016. Rastuća uloga banaka u realizaciji projekata energetske efikasnosti u Republici Srbiji. Bankarstvo 45 (3): 114-136.

10. Stojanovski, Đ. 2009. Ocena rentabilnosti i rizičnosti projektnog finansiranja. Bankarstvo 5-6: 30-51.

11. Uredba o uslovima i postupku sticanja statusa povlašćenog proizvođača električne energije, privremenog povlašćenog proizvođača i proizvođača električne energije iz obnovljivih izvora energije. Službeni glasnik RS, broj. 56/2016.

12. Zakon o javno-privatnom partnerstvu i koncesijama 2011/2016. Službeni glasnik RS, broj 88/11 i 15/2016. 
possibilities and opportunities that are being implemented daily. There are expectations that the problems of this type may be overcome with the implementation of activities aimed at raising awareness of the wider community about the importance of renewable energy projects, and by establishing more visible and stronger mechanisms of the market for energy services in the field of renewable energy. In this regard, closer cooperation between the public sector and potential investors would be relevant, as well as the active promotion of investment opportunities in the renewable energy sector.

RES projects represent a great potential for the banks themselves, with these business lines belonging both to the corporate sector and the household sector. There is no doubt that the above analyzed legislation in the field of renewable energy constitutes a necessary, but not sufficient basis for greater involvement of banks that already finance these projects and banks that are planning to introduce credit lines for the RES sector. The quality of the project proposal, its cost-effectiveness and capacity of the holders, to a large extent determine the level of risk in assessing the possibility of financing by the banks. In terms of financing the conditions in the project financing market in Serbia, there is a prevailing belief that the commercial legal risks associated with doing business in Serbia are still at a level above the average for the increased investments in the project finance market, and therefore in the project financing of renewable energy. No less significant are the risks at the level of the RES market in the Republic of Serbia. Good communication and cooperation that exists among the Ministry of Mining and Energy, banks and current and potential financiers, investors and other interested stakeholders is certainly a factor which has an affirmative role in the further improvement of the quality and depth of market financing of renewable energy projects in the Republic of Serbia. 